\title{
UPAYA PENGEMBANGAN POTENSI PARIWISATA DI KABUPATEN BULUNGAN
}

\author{
Oleh : Muhammad Syabranie *) dan Raja Jusmartinah ${ }^{* \star}$ )
}

\begin{abstract}
Abstrak
Salah satu sektor pembangunan yang hampir tidak terpengaruh oleh sistem kuota atau resesi ekonomi adalah sektor jasa yang didalamnya termasuk jasa pariwisata. Di masa yang akan datang diperkirakan pariwisata akan cederung meningkat. Kabupaten Bulungan, merupakan salah satu kabupaten yang berada di Propinsi Kalimantan Timur memiliki banyak potensi wilayah yang bisa dikembangkan menjadi obyek - obyek parisiwata yang selama ini terbengkalai tidak mendapatkan perhatian dari pemerintah.

Tujuan dari penelitian ini adalah untuk mendapatkan konsep pengembangan potensi pariwisata di kabupaten Bulungan, Kalimantan Timur berdasarkan faktor pendukung dan penghambat.

Metodologi penelitian ini menggunakan pendekatan Deskriptif yang menggambarkan secara tepat mengenai gejala - gejala obyek yang diteliti mengenai pengembangan potensi pariwisata di Kabupaten Bulungan. Sampel penelitian ini mengambil 11 obyek yang berpotensi dapat dikembangkan menjadi kawasan wisata yang kesemuanya tersebar di kabupaten Bulungan. Metode pengumpulan data menggunakan observasi dan wawancara untuk mendapatkan data primer serta penumpulan literatur pendukung obyek untuk mendapatkan data sekunder. Analisis yang digunakan adalah analisis SWOT untuk mendapatkan konsep pengembangan berdasarkan pendukung dan penghambat pengembangan kawasan.

Hasil dari penelitian ini adalah yang menjadi pendukung berupa keunikan dari obyek - obyek wisata sehingga dapat membentuk jalur - jalur wisata sesuai dengan pengklasifikasian potensi dari obyek wisata yang tersebar di kabupaten Bulungan. Jalur - jalur wisata berupa paket wisata yang terdiri dari paket wisata alam ( Pantai Tanah kuning, Air terjun Km 18, Air Hutan Gunung Seriang Km 2, Pantai Bahari Karang Tigau, dan Pantai Nibung), paket wisata religi (Makam keluarga Datu Adil, Makam Keramat Ahmad Maghribi, dan Masjid Tua), serta paket wisata budaya (Gunung Putih, dan Keraton Kesultanan Bulungan ). Penghambat dari pengembangan adalah kurang dukungan investor dan juga SDM yang mempunyai kemampuan bersaing.
\end{abstract}

Kata Kunci : Potensi Obyek wisata, Pengembangan, Pariwisata, Kabupaten Bulungan,

\section{PENDAHULUAN}

Indonesia memiliki tujuan nasional yang salah satunya adalah memajukan kesejahteraan umum, sebagaimana dengan yang tercantum pada Pembukaan Undangundang Dasar 1945 alinea keempat. Tujuan nasional tersebut diwujudkan melalui pelaksanaan penyelenggaraan negara yang berkedaulatan rakyat dan demokratis dengan mengutamakan persatuan dan kesatuan bangsa serta berdasarkan Pancasila dan UUD 1945. Penyelenggaraan negara dilaksanakan melalui pembangunan nasional dalam segala aspek kehidupan bangsa, seperti yang tercantum dalam lampiran Undang-undang No.25 tahun 2000 tentang Program Pembangunan Nasional (Propernas) tahun 2000-2004. Program Pembangunan Nasional meliputi pembangunan hukum, ekonomi, politik, agama, pendidikan, sosial budaya, pembangunan daerah, sumber daya alam dan lingkungan hidup, serta pembangunan pertahanan dan keamanan.Terkait dengan pembangunan ekonomi, Indonesia banyak memiliki sumber yang dapat diandalkan. Dalam bukunya yang berjudul Transformasi ekonomi Indonesia, Hal Hill menyebutkan pada waktu terjadi boom minyak, investasi mengalami peningkatan pesat hingga mencapai 30\% dari Produk Domestik Bruto, kenaikan dolar pun pesat. Kemudian pada pertengahan 1973, harga minyak internasional naik empat kali lipat, yang membuat Indonesia mendapat keuntungan yang besar dari minyak mengingat Indonesia kaya akan sumber daya alam terutama migas.

\footnotetext{
*) Mahasiswa Perencanaan Wilayah Kota

*)Dosen Perencanaan Wilayah Kota

Universitas PGRI Adi Buana Surabaya
} 
Pada tahun 1982-1986, jatuhnya harga minyak mengakibatkan meningkatnya utang luar negeri dan penurunan pertumbuhan ekonomi yang juga berakhirnya masa pertumbuhan yang didanai oleh minyak dan berakhirnya era dana yang melimpah. (Hal Hill, 1996:6\&24).

Berpijak pada latar belakang, maka dapat ditentukan rumusan masalah yang akan dibahas dalam skripsi ini yaitu, bagaimana upaya pengembangan potensi pariwisata di Kabupaten Bulungan. Menurut bahasa Sansekerta dalam Yoeti (1982:103) "Pariwisata berasal dari dua suku kata yaitu masing-masing kata "pari" yang berarti banyak, berkali-kali, berputar-putar, lengkap dan "wisata" yang berarti perjalanan, berpergian, yang dala hal ini sinonim dengan kata "travel" dalam bahasa inggris". Selanjutnya E. Guyer Freuler dalam Yoeti (1982:105) merumuskan pariwisata dengan memberikan batasan sebagai "Pariwisata dalam artian modern adalah merupakan phenomena dari jaman sekarang yang didasarkan atas kebutuhan akan kesehatan dan pergantian hawa, penilaian yang sadar dan menumbuhkan (cinta) terhadap keindahan alam dan pada khususnya disebabkan oleh bertambahnya pergaulan berbagai bangsa dan kelas masyarakat manusia sebagai hasil daripada perkembangan perniagaan, industri, perdagangan, serta penyempurnaan dari pada alat-alat pengangkutan".

Menurut Undang-undang No.9 Tahun 1990 Tentang Kepariwisataan dalam Pasal 1 (3) : Pariwisata adalah segala sesuatu yang berhubungan dengan wisata, termasuk pengusahaan obyek dan daya tarik wisata serta usaha-usaha yang terkait di bidang tersebut. Dari definisi-definisi di atas, dapat ditarik kesimpulan bahwa pariwisata adalah suatu fenomena yang dilakukan oleh manusia yang berhubungan dengan kegiatan-kegiatan wisata, seperti motif untuk mencari udara segar dan menikmati keindahan alam, kegiatan yang ditujukan untuk memenuhi kebutuhan wisatawan, dan sebagainya. Ditinjau dari segi bahasa
Sansekerta seperti yang dikemukakan oleh Yoeti (1982:120) adalah "Bahwa kata itu berasal dari kata "wisata" yang berarti "perjalanan" yang sama atau dapat disamakan dengan kata "travel" dalam bahasa Inggris. Jadi, orang yang melakukan perjalanan dalam pengertian ini, maka "wisatawan" sama artinya dengan kata "tarveler", karena dalam bahasa Indonesia sudah merupakan kelaziman pemakaian akhiran "...wan" untuk menyatakan orang dengan profesinya, keahliannya, keadaannya, jabatannya, kedudukan seseorang".Menurut G. A. Schmoll dalam Yoeti (1982:127) mengatakan bahwa "Wisatawan adalah individu atau kelompok individu yang mempertimbangkan dan merencanakan tenaga beli yang dimilikinya untuk perjalanan rekreasi dan berlibur, yang tertarik dengan perjalanan pada umumnya dengan motivasi perjalanan yang pernah ia lakukan, menambah pengetahuan, tertarik oleh pelayanan yang diberikan oleh suatu daerah tujuan wisata yang dapat menarik pengunjung di masa yang akan datang".Jadi dapat ditarik kesimpulan bahwa wisatawan merupakan pengunjung sementara yang tinggal sekurang-kurangnya 24 jam di negara yang bersangkutan, dimana orangorang tersebut mempunyai motif perjalanan yang beragam, diantaranya : Liburan, kesenangan, belajar, olah raga, keagamaan, dan sebagainya. Dalam Yoeti (1982:158) disebutkan bahwa: "Untuk pengertian obyek wisata lebih banyak menggunakan istilah "tourist attractions", yaitu segala sesuatu yang menjadi daya tarik bagi orang untuk mengunjungi suatu daerah tertentu".. Selanjutnya Chalik Hamid (1996:27) mengartikan bahwa: "Obyek wisata adalah segala sesuatu yang menarik dan telah dikunjungi wisatawan. Sedang daya tarik adalah segala sesuatu yang menarik namun belum tentu dikunjungi wisatawan". Dalam Chalik Hamid (1996:27) membedakan obyek dan daya tarik wisata sebagai berikut:

Site Attraction yaitu obyek yang bersifat statis, seperti tempat yang memiliki iklim yang menyenangkan, pemandangan yang indah ataupun tempat-tempat yang 
bersejarah. Event Attraction Yakni obyek yang bersifat hidup, seperti kejadian atau perisitiwa kongres, festival, olah raga, kesenian, dan lain-lain. Sehingga dapat disimpulkan bahwa obyek dan daya tarik wisata adalah sesuatu yang dimiliki oleh suatu daerah sehingga membuat daerah tersebut dikunjungi oleh wisatawan, karena wisatawan merasa tertarik dengan apa yang dimiliki oleh daerah yang dikunjungi tersebut

\section{METODOLOGI PENELITIAN}

Jenis penelitian yang bersifat deskriptif ini memiliki tujuan untuk menggambarkan secara tepat mengenai gejala-gejala obyek yang akan diteliti mengenai pengembangan potensi pariwisata di Kabupaten Bulungan Terkait dengan pembangunan di bidang pariwisata, maka analisis SWOT dapat dikatakan sebagai upaya administratif pemerintah untuk mengelola sumber-sumber pariwisata karena kemampuan administratif dapat mempengaruhi pengembangan sektor pariwisata. Dalam bukunya Drs. H. Oka Yoeti, MBA yang berjudul Anatomi Pariwisata, analisis SWOT yaitu analisis untuk mengetahui dan menginventarisasi faktor-faktor Kekuatan (Strenghts) Kekuatan apa saja yang dimiliki pariwisata Indonesia. Dengan mengetahui kekuatan pariwisata Indonesia dapat dikembangkan menjadi lebih tangguh hingga mampu bertahan dalam pasar dan mampu bersaing untuk pengembangan selanjutnya. Cukup diketahui, kekuatan pariwisata Indonesia terletak pada potensi alam yang besar dan seni budaya yang tinggi. Kelemahan (Weaknesses) yaitu segala faktor yang tidak menguntungkan atau merugikan bagi sektor pariwisata. Dalam hal pariwisata Indonesia, kelemahan-kelemahan ini berupa kurangnya promosi, buruknya pelayanan, keselamatan wisatawan yang tidak terjamin, kurang profesionalnya pelaksana pariwisata di lapangan, serta terbatasnya kendaraan umum ke obyek-obyek wisata. Kesempatan (Opportunities) yaitu semua kesempatan yang ada sebagai akibat kebijakan pemerintah, peraturan yang berlaku, atau kondisi perekonomian nasional atau global yang dianggap dapat memberi peluang bagi pariwisata Indonesia untuk tumbuh dan berkembang di masa-masa mendatang. Ancaman (Threats) Yang dimaksud dengan ancaman disini adalah hal-hal yang dapat mendatangkan kerugian bagi pariwisata Indonesia, seperti rusaknya lingkungan atau gejolak sosial. Sifat analisis SWOT ini sangat situasional. Artinya hasil analisis tahun sekarang belum tentu akan sama dengan hasil analisis tahun yang akan datang. Kecuali kalau semua faktor yang mempengaruhi juga berubah. Biasanya hasil analisis akan banyak ditentukan oleh faktorfaktor situasi dan kondisi ekonomi, politik, stabilitas keamanan dan keadaan sosial yang melatar belakangnya. Keempat faktor itu perlu mendapat perhatian khusus. Kekuatan harus dipertahankan sebaikbaiknya. Kelemahan harus dihilangkan dengan segera. Kesempatan atau peluang hendaknya segera dimanfaatkan dan ancaman atau tantangan harus segera diantisipasi. Dengan demikian, dapat diambil langkah-langkah perbaikan dalam pembangunan. Faisal (1990:90) mengemukakan bahwa prosedur analisis data dalam penelitian kualitatif ada 2 tahap, yaitu : pertama, dilakukan pada waktu peneliti berada di lapangan untuk mengumpulkan data. Kedua, analisis data dilakukan setelah proses pengumpulan data atau setelah peneliti meninggalkan latar penelitian.Setelah melakukan pengumpulan data, analisa data dimulai dengan menelaah seluruh data yang tersedia dari berbagai sumber. 


\section{HASIL PENELITIAN}

Hasil analisis dari mengidentifikasikan potensi obyek wisata di kabupaten Bulungan di jabarkan dalam tabel 1 dibawah ini.

Tabel 1

Identifikasi Potensi Wisata di Kabupaten Bulungan

\begin{tabular}{|c|c|c|}
\hline Lokasi Wisata & Potensi atau Kelebihan & Permasalahan atau Kekurangan \\
\hline $\begin{array}{l}\text { 1. Gunung } \\
\text { Putih (Kec. } \\
\text { Tg. Palas) }\end{array}$ & $\begin{array}{l}\text { - Obyek wisata unggulan kabupaten } \\
\text { bulungan } \\
\text { - Ikon penting bagi kec. Tg. Palas } \\
\text { - Gunung kapur berwarna putih } \\
\text { - Relief-relief yang alami dan sangat indah } \\
\text { - Sangat diminati oleh penggemar hiking } \\
\text { - Dari puncak bisa menikmati } \\
\text { pemandangan alam yang eksotis dan } \\
\text { menyejukkan mata seperti ada sungai } \\
\text { kecil disisi gunung, serta pemandangan } \\
\text { hijau yang menyenangkan } \\
\text { - Terdapat goa burung yang dipercaya } \\
\text { merupakan tempat tafakur/menenangkan } \\
\text { diri Sultan Bulungan } \\
\text { - Bisa menikmati kesenian daerah di } \\
\text { rumah panggung di sekitar lokasi }\end{array}$ & $\begin{array}{l}\text { - Banyak sampah yang berserakan di } \\
\text { sekitar lokasi } \\
\text { - Kurangnya penerangan } \\
\text { - Saat menuju puncak tidak memiliki } \\
\text { tempat peristirahatan (warung / gazebo) } \\
\text { - Event kesenian dirumah panggung } \\
\text { hanya } 1 \text { tahun sekali atau ada } \\
\text { kunjungan dari pemerintah dan } \\
\text { wisatawan luar negeri }\end{array}$ \\
\hline $\begin{array}{l}\text { 2. Keraton } \\
\text { Kesultanan } \\
\text { Bulungan } \\
\text { (Kec. Tg. } \\
\text { Palas) }\end{array}$ & $\begin{array}{l}\text { - Obyek wisata unggulan kabupaten } \\
\text { bulungan } \\
\text { - Dibangun kembali tahun } 1998 \text { di Istana } \\
\text { Bulungan } \\
\text { - Memiliki benda-benda bersejarah } \\
\text { peninggalan kesultanan bulungan seperti } \\
\text { tempat tidur sultan, foto-foto, kursi, meja, } \\
\text { dan duplikat baju kebesarannya. } \\
\text { - Disekitar lokasi terdapat peninggalan } \\
\text { kerjaan bulungan berupa alat perang } \\
\text { (meriam) yang bernama Melati, Rindu } \\
\text { dan Dendam }\end{array}$ & $\begin{array}{l}\text { - Benda-benda bersejarah yang masih } \\
\text { kurang tertata dan terawat dengan baik } \\
\text { - Kurangnya sarana dan prasarana } \\
\text { pendukung di sekitar lokasi } \\
\text { - benda-benda sejarah yang ada } \\
\text { merupakan duplikat, sebagian yang asli } \\
\text { terdapat di museum Belanda }\end{array}$ \\
\hline $\begin{array}{l}\text { 3. Pantai } \\
\text { Tanah } \\
\text { Kuning } \\
\text { (Kec. Tg. } \\
\text { Palas } \\
\text { Timur) }\end{array}$ & $\begin{array}{l}\text { - Obyek wisata unggulan kabupaten } \\
\text { unggulan } \\
\text { - Memiliki hamparan pasir yang putih } \\
\text { bersih } \\
\text { - Kondisi yang masih alami } \\
\text { - Memiliki lebar + } 75 \text { m dengan panjang + } \\
2 \mathrm{~km} \\
\text { - Memberikan kenyamanan untuk } \\
\text { berjemur dan bermain pasir bersama } \\
\text { teman dan keluarga }\end{array}$ & $\begin{array}{l}\text { - Memiliki permasalahan lahan dengan } \\
\text { warga setempat } \\
\text { - Akses jalur darat ke lokasi sulit karena } \\
\text { kondisi jalan banyak yang rusak } \\
\text { - Tidak tersedia sarana dan prasarana di } \\
\text { sekitar lokasi }\end{array}$ \\
\hline $\begin{array}{l}\text { 4. Mesjid Tua } \\
\text { (Kec. Tg. } \\
\text { Palas) }\end{array}$ & $\begin{array}{l}\text { - Dibangun pada tahun } 1929 \\
\text { - Peninggalan kerajaan bulungan }\end{array}$ & $\begin{array}{l}\text { - Kurangnya promosi dan penjelasan } \\
\text { sejarah mesjid }\end{array}$ \\
\hline $\begin{array}{l}\text { 5. Air Terjun } \\
\text { KM18 (Kec. } \\
\text { Tg. Selor) }\end{array}$ & $\begin{array}{l}\text { - Air terjun dengan ketinggian } 15 \text { meter } \\
\text { - Memiliki } 3 \text { tingkat air terjun } \\
\text { - Jarak dari kota tg. Selor ditempuh }-/+45 \\
\text { menit }\end{array}$ & $\begin{array}{l}\text { - Tidak terawat dan tertata dengan baik } \\
\text { - Dari gerbang masuk sangat jauh sekitar } \\
\text {-/+ } 1 \text { jam berjalan kaki menuju lokasi } \\
\text { - Medan ke lokasi sangat sulit, lereng } \\
\text { yang curam dan tidak semua memiliki } \\
\text { anak tangga } \\
\text { - Di lokasi tidak ada sarana dan prasrana }\end{array}$ \\
\hline
\end{tabular}




\begin{tabular}{|c|c|c|}
\hline & & $\begin{array}{l}\text { - Adanya isu angker (putri yang sering } \\
\text { menganggu pengunjung) }\end{array}$ \\
\hline \begin{tabular}{|l|} 
6. Sumber \\
Air Panas \\
(Kec. Tg. \\
Palas \\
Timur) \\
\end{tabular} & $\begin{array}{l}\text { - Air panas yang berasal dari panas bumi } \\
\text { - Dengan panasnya dapat merebus telur } \\
\text { didalamnya } \\
\text { - Keindahan alam yang masih asri }\end{array}$ & $\begin{array}{l}\text { - Tidak ada penataan yang baik disekitar } \\
\text { lokasi } \\
\text { - Terkesan liar dan masih alami }\end{array}$ \\
\hline $\begin{array}{l}\text { 7. Makam } \\
\text { Keramat } \\
\text { Ahmad } \\
\text { Maghribi } \\
\text { (Kec. Tg. } \\
\text { Palas } \\
\text { Tengah) }\end{array}$ & $\begin{array}{l}\text { - Makam ini dapat ditempuh + } 30 \text { menit } \\
\text { dari kota tg. Selor dengan menggunakan } \\
\text { speed boad } \\
\text { - + } 300 \text { metern dari makam ini terdapat } \\
\text { pula dua makam lainnya yaitu : makam } \\
\text { Sayid Ali Idrus dan Sayid Abdullah } \\
\text { Bilfagih } \\
\text { - Menurut cerita masyarakat setempat } \\
\text { dahulu kala ada seorang hamba allah } \\
\text { yang taat beribadah kepada Allah dan } \\
\text { banyak mebantu di dalam kehidupan } \\
\text { masyarakat, sehingga ia banyak } \\
\text { disenangi orang-orang disekitarnya. } \\
\text { Pada saat ia meninggal terjadi suatu } \\
\text { keanehan dimana pada saat jenazahnya } \\
\text { akan diturunkan ke liang lahat saat itu } \\
\text { tepat waktu solat magrib. Tetapi diluar } \\
\text { dugaan matahari tetap bertahan sama } \\
\text { persis waktu jam 05.00 sore hari. Begitu } \\
\text { selesai dikebumikan keadaan tiba-tiba } \\
\text { gelap gulita kembali seperti sedia kala di } \\
\text { malam hari. Maka makam itu dianggap } \\
\text { keramat dan dinamakan Makam } \\
\text { Keramat Ahmad Maghribi }\end{array}$ & $\begin{array}{l}\text { - Akses ke lokasi hanya bisa ditempuh } \\
\text { transportasi air } \\
\text { - Belum adanya jalur wisata ke lokasi }\end{array}$ \\
\hline \begin{tabular}{|l|} 
8. \\
Kakam \\
Keluarga \\
Datu Adil \\
(Kec. Tg. \\
Palas \\
Tengah) \\
\end{tabular} & $\begin{array}{l}\text { - Lokasi dapat dicapai lewat jalur sungai - } \\
\text { /+ } 30 \text { menit } \\
\text { - Menurut legenda, Datu Adil adalah } \\
\text { kerabat kesultanan bulungan dan ia } \\
\text { terkenal sebagai pemimpin yang adil } \\
\text { dan bijaksana }\end{array}$ & $\begin{array}{l}\text { - Kurangnya promosi } \\
\text { - Tidak ada jalur wisata }\end{array}$ \\
\hline $\begin{array}{l}\text { 9. } \text { Makam } \\
\text { Said Ali Al } \\
\text { Idrus (Kec. } \\
\text { Tg. Palas } \\
\text { Tengah) }\end{array}$ & $\begin{array}{l}\text { - Berdekatan dengan lokasi makam } \\
\text { keramat Ahmad Maghribi sekitar + } 300 \mathrm{~m} \\
\text { - Sayid Ali Idrus dan Sayid Abdullah } \\
\text { Bilfaqih, mereka berdua adalah orang } \\
\text { yang pertama kali menyebarkan agama } \\
\text { islam di Kec. Tg. Palas } \\
\end{array}$ & $\begin{array}{l}\text { - Kurangnya promosi } \\
\text { - Tidak ada jalur wisata }\end{array}$ \\
\hline $\begin{array}{l}\text { 10. Pemandia } \\
\text { n Air } \\
\text { Hutan } \\
\text { KM2 (Kec. } \\
\text { Tg. Selor) } \\
\end{array}$ & $\begin{array}{l}\text { - Aliran air hutan yang menyegarkan dan } \\
\text { nampak indah di musim penghujan } \\
\text { - Kondisi hutan yang masih rapat. } \\
\text { - Jarak tempuh }-/+15 \text { menit dari jalan raya } \\
\text { dengan berjalan kaki }\end{array}$ & $\begin{array}{l}\text { - Kondisi jalan menuju lokasi banyak } \\
\text { yang rusak } \\
\text { - Tidak tertata dan terawat dengan baik } \\
\text { - Tidak ada pengurus dari pemerintah } \\
\text { yang khusus menangani lokasi } \\
\end{array}$ \\
\hline $\begin{array}{l}\text { 11. Air Terjun } \\
\text { Long Pin } \\
\text { (Kec. } \\
\text { Peso) }\end{array}$ & $\begin{array}{l}\text { - Pemandangan yang indah } \\
\text { - Air yang jernih } \\
\text { - Di bagian hilir membentuk danau yang } \\
\text { indah } \\
\text { - Dikelilingi bebatuan yang alami }\end{array}$ & $\begin{array}{l}\text { - Kurangnya promosi } \\
\text { - Lokasi yang sangat jauh dari kota } \\
\text { tg.selor } \\
\text { - Kurangnya perhatian pemerintah untuk } \\
\text { merawat lokasi wisata }\end{array}$ \\
\hline $\begin{array}{l}\text { 12. Pantai } \\
\text { Bahari } \\
\text { Karang } \\
\text { Tigau } \\
\text { (Kec. Tg. }\end{array}$ & $\begin{array}{l}\text { - Memiliki hamparan pasir putih } \\
\text { - Gelombang laut yang tidak begitu besar } \\
\text { - Sangat cocok untuk lokasi memancing } \\
\text { dan berolahraga }\end{array}$ & $\begin{array}{l}\text { - Kurangnya promosi } \\
\text { - Tidak tersedia sarana dan prasarana } \\
\text { pendukung disekitar lokasi } \\
\text { - Akses jalur darat ke lokasi sulit karena } \\
\text { kondisi jalan banyak yang rusak }\end{array}$ \\
\hline
\end{tabular}




\begin{tabular}{|c|c|c|}
\hline $\begin{array}{l}\text { Palas } \\
\text { Timur) }\end{array}$ & & \\
\hline $\begin{array}{l}\text { 13. Pantai } \\
\text { Nibung } \\
\text { (Kec. } \\
\text { Bunyu) }\end{array}$ & $\begin{array}{l}\text { - Paduan hamparan pasir putih sepanjang } \\
500 \mathrm{~m} \\
\text { - Lambaian nyiur kelapa yang } \\
\text { mengundang kita untuk memanjakan diri } \\
\text { - Keindahan panorama yang alami dan } \\
\text { asri }\end{array}$ & $\begin{array}{l}\text { - Mempunyai isu angker disebabkan } \\
\text { pengunjung yang cedera dan meninggal } \\
\text { di lokasi wisata }\end{array}$ \\
\hline $\begin{array}{l}\text { 14. Pulau } \\
\text { Burung } \\
\text { (Kec. } \\
\text { Bunyu) }\end{array}$ & $\begin{array}{l}\text { - Dahulu dihuni oleh berbagai macam } \\
\text { spesies burung, saat ini hanya tinggal } \\
\text { beberapa spesies saja } \\
\text { - Memiliki panorama alam yang indah dan } \\
\text { alami }\end{array}$ & $\begin{array}{l}\text { - Kurangnya promosi } \\
\text { - Tidak memiliki sarana dan prasrana } \\
\text { pendukung } \\
\text { - Tidak ada tindakan perlindungan dan } \\
\text { pelestarian terhadap spesies yang ada } \\
\text { di lokasi wisata }\end{array}$ \\
\hline
\end{tabular}

Sumber : Hasil Identifikasi 2013

\section{PEMBAHASAN}

Pembahasan mengenai upaya Pengembangan sarana dan prasarana di obyek wisata kabupaten Bulungan akan dijabarkan pada tabel 2 dibawah ini.

Tabel 2

Pengembangan Sarana dan Prasana di Kabupaten Bulungan

\begin{tabular}{|c|c|c|}
\hline $\begin{array}{l}\text { Sarana dan } \\
\text { Prasana }\end{array}$ & Kondisi & $\begin{array}{c}\text { Upaya } \\
\text { Pengembangan }\end{array}$ \\
\hline Transportasi & $\begin{array}{l}\text { - Kondisi jalan darat yang rusak mencapai } \\
31 \%(259,53 \mathrm{~km}) \text {. } \\
\text { - Transportasi air hanya melayani antar } \\
\text { Kecamatan } \\
\text { - Belum ada transportasi khusus ke lokasi } \\
\text { wisata }\end{array}$ & $\begin{array}{l}\text { - DPU harus meprioritaskan pembangunan } \\
\text { maupun perbaikan jalan yang menuju } \\
\text { lokasi wisata } \\
\text { - Dinas Perhubungan harus mengusahakan } \\
\text { adanya angkutan-angkutan khusus yang } \\
\text { menuju lokasi obyek wisata }\end{array}$ \\
\hline komunikasi & $\begin{array}{l}\text { - Sudah cukup lengkap, namun masih } \\
\text { terpusat di Kecamatan Tanjung Selor } \\
\text { - Belum ada fsilitas komunikasi dan } \\
\text { internet di beberapa titik lokasi wisata }\end{array}$ & $\begin{array}{l}\text { - mengadakan fasilitas internet, sehingga } \\
\text { komunikasi pun semakin luas dan dapat } \\
\text { menjangkau seluruh dunia, serta } \\
\text { memudahkan wisatawan } \\
\text { berkomunikasi. untuk }\end{array}$ \\
\hline listrik & $\begin{array}{l}\text { - Fasilitas listrik yang ada di sudah } \\
\text { tersedia secara merata terutama di } \\
\text { pusat-pusat kecamatan } \\
\text { - Terdapat keluhan dari masyarakat } \\
\text { mengenai seringnya diadakan } \\
\text { pemadaman listrik. Hal tersebut } \\
\text { disebabkan karena kerusakan mesin } \\
\text { diesel yang dimiliki oleh PLN setempat. } \\
\text { - Tidak adanya fasilitas listrik hampir } \\
\text { semua di sebagian lokasi obyek wisata }\end{array}$ & $\begin{array}{l}\text { - Pemerintah Kabupaten Bulungan bersama } \\
\text { dengan PLN perlu mengusahakan untuk } \\
\text { membeli mesin baru } \\
\text { - Dinas Kebudayaan dan Pariwisata perlu } \\
\text { mengupayakan fasilitas listrik }\end{array}$ \\
\hline Air bersih & $\begin{array}{l}\text { - konsumsi air berasal dari perusahaan air } \\
\text { minum (PDAM) } \\
\text { - air bersih sudah tersedia pada sebagian } \\
\text { obyek wisata }\end{array}$ & $\begin{array}{l}\text { - Diharapkan Dinas Kebudayaan dan } \\
\text { Pariwisata bekerja sama dengan PDAM } \\
\text { mengupayakan ketersediaan air bersih di } \\
\text { sebagian obyek wisata yang belum } \\
\text { tersedia air bersih, sehingga dapat } \\
\text { memperlancar arus kunjungan wisatawan }\end{array}$ \\
\hline Perbankan & $\begin{array}{l}\text { - Terdapat bank pemerintah dan bank } \\
\text { swasta di Kecamatan Tg. Selor }\end{array}$ & $\begin{array}{l}\text { - pemerintah harus lebih memperhatikan } \\
\text { lagi pengadaan cabang-cabang bank } \\
\text { pemerintah di lokasi agak terpencil seperti }\end{array}$ \\
\hline
\end{tabular}




\begin{tabular}{|c|c|c|}
\hline & & di Kecamatan Tg. Palas Timur \\
\hline Keamanan & $\begin{array}{l}\text { - Terdapat Kepolisian } \\
\text { - Terdapat Pemadam Kebakaran }\end{array}$ & $\begin{array}{l}\text { - Pemerintah Kabupaten Bulungan } \\
\text { melakukan kerjasama dengan Kepolisian, } \\
\text { Pemadam Kebakaran serta instansi terkait } \\
\text { yang membidangi keamanan dan } \\
\text { keselamatan } \\
\text { - Di lokasi wisata harus dilengkapi dengan } \\
\text { tanda-tanda larangan yang bertujuan } \\
\text { untuk menjaga keselamatan wisatawan } \\
\end{array}$ \\
\hline Kesehatan & $\begin{array}{l}\text { - terdapat di lbukota Kabupaten serta } \\
\text { lebih dari } 100 \text { Puskesmas yang tersebar } \\
\text { di seluruh kecamatan termasuk } \\
\text { didalamnya daerah kawasan wisata }\end{array}$ & $\begin{array}{l}\text { - Pemenuhan fasilitas kesehatan yang } \\
\text { sudah tersedia juga harus didukung } \\
\text { pemenuhan tenaga kesehatan yang } \\
\text { memadai }\end{array}$ \\
\hline $\begin{array}{c}\text { Restoran / } \\
\text { Rumah Makan }\end{array}$ & $\begin{array}{l}\text { - Jumlah rumah makan yang ada di } \\
\text { Kabupaten } \text { Bulungan } \\
\text { keseluruhan berjumlah } 16 \text { buah } \\
\text { - banyak rumah makan liar bersekala kecil } \\
\text { yang terdapat di lokasi obyek wisata }\end{array}$ & $\begin{array}{l}\text { - Dikembangkan lagi di sekitar obyek wisata } \\
\text { dan ditata sedemikian rupa serta rumah } \\
\text { makan liar yang ada diadakan penertiban }\end{array}$ \\
\hline $\begin{array}{c}\text { Biro } \\
\text { Perjalanan }\end{array}$ & - Belum ada & $\begin{array}{l}\text { - Dinas Kebudayaan dan Pariwisata perlu } \\
\text { merespon situasi tersebut dengan } \\
\text { melakukan kerja sama dengan sektor } \\
\text { swasta atau pengusaha setempat untuk } \\
\text { mengusahakan adanya biro perjalanan }\end{array}$ \\
\hline
\end{tabular}

\section{Pemecahan Masalah}

Selain memiliki faktor-faktor yang dapat mendukung upaya pengembangan potensi pariwisata di Kabupaten Bulungan, Dinas Pariwisata dan Kebudayaan Kabupaten Bulungan menghadapi beberapa kendala yang dapat mempengaruhi proses pengembangan tersebut. Dari data yang disajikan maka; faktor pendukung berupa :

1. keaslian obyek wisata alam

2. budaya dan kesenian tradisional yang merupakan produk wisata daerah.

3. keuangan yang dimiliki relatif cukup memadai.

Sementara faktor penghambat yang dihadapi adalah :

1. Kuantitas dan kualitas yang belum memadai

Dalam hal ini kualitas yang dimaksud adalah mengenai sumber daya manusianya.

2. Selanjutnya sarana dan prasarana ke tempat obyek wisata masih minim.

3. Kondisi jalan ke lokasi wisata yang kurang terawat.
Faktor pendukung dan penghambat diidentifikasikan sebagai kekuatan dan kelemahan yang merupakan analisis lingkungan internal. Sedangkan analisis lingkungan eksternal mempertimbangkan kekuatan dan kelemahan yang dihadapi sehingga menimbulkan peluang dan ancaman sebagai berikut;

Peluang meliputi :

1. Adanya Undang - undang No. 22 tahun 1999 dan PP No.25 tahun 2000 tentang otonomi daerah.

2. Animo masyarakat yang cukup tinggi untuk memanfaatkan obyek wisata.

3. Banyaknya obyek wisata yang belum tergali.

4. Posisi geografis yang strategis.

5. Terdapat situs sejarah yang menarik untuk dikunjungi.

Ancaman meliputi :

1. Sarana dan prasarana yang belum mendukung keberadaan obyek wisata.

2. Belum adanya biro perjalan yang mendukung. 
3. Letak geografis obyek wisata yang terpencar pencar.

Berdasarkan analisis SWOT tersebut, maka dapat ditentukan Critical Success Faktor dengan strategi pada tabel berikut :
4. Jumlah penduduk yang masih sedikit dan tidak terkonsentrasi pada satu wilayah.

Tabel 3

Analisis Strategik Dengan Faktor SWOT

\begin{tabular}{|c|c|c|}
\hline & Peluang (0) & Ancaman (T) \\
\hline A LE & $\begin{array}{l}\text { - Keanekaragaman } \\
\text { budaya / kesenian } \\
\text { tradisional } \\
\text { - Obyek wisata yang } \\
\text { bersifat alami } \\
\text { - Keuangan yang cukup } \\
\text { memadai }\end{array}$ & $\begin{array}{l}\text { - Kuantitas dan kualitas relatif } \\
\text { belum memadai } \\
\text { - Sarana dan prasarana yang } \\
\text { ada belum cukup } \\
\text { - Banyaknya kondisi jalan } \\
\text { yang rusak ke lokasi wisata }\end{array}$ \\
\hline Kekuatan (S) & $\mathrm{S}+0$ & $S+T$ \\
\hline $\begin{array}{l}\text { - Adanya UU No. } 22 \text { tahun } \\
1999 \text { dan PP No. } 25 \text { tahun } \\
1999 \text { tentang Otonomi } \\
\text { Daerah } \\
\text { - Animo masyarakat yang } \\
\text { cukup tinggi untuk } \\
\text { memanfaatkan obyek wisata } \\
\text { - Banyaknya obyek wisata } \\
\text { yang belum tergali } \\
\text { - Posisi geografis yang } \\
\text { strategis } \\
\text { - Terdapat situs sejarah yang } \\
\text { menarik untuk dikunjungi }\end{array}$ & $\begin{array}{l}\text { Kembangkan potensi } \\
\text { obyek wisata yang } \\
\text { belum tergali dengan } \\
\text { memanfaatkan dana } \\
\text { yang tersedia } \\
\text { - Berdayakan } \\
\text { masyaarakat disekitar } \\
\text { obyek wisata } \\
\text { - Tingkatkan pembinaan } \\
\text { seni dan budaya } \\
\text { daerah }\end{array}$ & $\begin{array}{l}\text { - Koordinasi dengan lintas } \\
\text { sektor agar pembangunan } \\
\text { sarana dan prasarana dapt } \\
\text { diwujudkan } \\
\text { - Lakukan kerjasama dengan } \\
\text { biro perjalanan } \\
\text { - Perluas jaringan informasi }\end{array}$ \\
\hline Kelemahan (W) & $\mathbf{W}+\mathbf{O}$ & $W+T$ \\
\hline $\begin{array}{l}\text { - Sarana dan prasarana yang } \\
\text { belum mendukung } \\
\text { keberadaan obyek wisata } \\
\text { - Belum adanya biro perjalan } \\
\text { yang mendukung } \\
\text { - Letak geografis obyek wisata } \\
\text { yang terpencar - pencar }\end{array}$ & $\begin{array}{l}\text { - Tingkatkan kualitas } \\
\text { SDM } \\
\text { - Lengkapi sarana dan } \\
\text { prasarana operasional }\end{array}$ & $\begin{array}{l}\text { - Maksimalkan penggunaan } \\
\text { sarana dan prsarana }\end{array}$ \\
\hline
\end{tabular}

Berdasarkan strategi di atas dan dengan mempertimbangkan prioritas utama maka dapat ditentukan pemecahan masalah sebagai berikut :

1. Mengembangkan potensi obyek wisata yang belum tergali dengan memanfaatkan dana yang tersedia.
2. Memberdayakan masyarakat di sekitar obyek wisata.

3. Meningkatkan pembinaan seni budaya daerah.

4. Melakukan koordinasi yang baik dengan lintas sektor agar pembangunan sarana dan prasarana dapat diwujudkan.

5. Melakukan kerjasama dengan sektor swasta untuk mengadakan biro perjalanan. 
6. Meningkatkan kualitas SDM. Dengan adanya analisis SWOT ini maka sudah seyogyanya Kantor Kebudayaan dan Pariwisata Kabupaten Bulungan sebagai suatu institusi yang bertanggung jawab dalam pengembangan potensi pariwisata memanfaatkan analisis SWOT sebagai suatu kerangka kerja yang dapat mengatasi permasalahan yang dihadapi dalam mengembangkan potensi pariwisata yang ada di Kabupaten Bulungan.

\section{KESIMPULAN DAN SARAN}

Dari jenis - jenis obyek wisata yang terdapat di Kabupaten Bulungan secara umum memiliki prospek yang cerah untuk dikembangkan baik wisata alam, wisata sejarah dan budaya, serta pariwisata alternatif seperti agrowisata.. Secara umum upaya yang telah dilakukan Dinas Pariwisata dan Kebudayaan untuk mengembangkan potensi pariwisata di Kabupaten Bulungan belum optimal. Dalam pengembangan potensi pariwisata di Kabupaten Bulungan, Dinas Pariwisata dan Kebudayaan Kabupaten Bulungan menghadapi beberapa kendala yaitu kuantitas dan kualitas yang belum memadai mengenai sumber daya manusianya, sarana dan prasarana ke tempat obyek wisata masih minim, dan kondisi jalan ke lokasi wisata yang kurang terawat. Di samping itu, Dinas Pariwisata dan Kebudayaan juga memiliki faktor pendukung yang dapat menunjang pengembangan potensi pariwisata di Kabupaten Bulungan yaitu keaslian obyek wisata alam, budaya dan kesenian tradisional yang merupakan produk wisata daerah, dan keuangan yang dimiliki relatif cukup memadai. Berdasarkan analisis SWOT maka dapat ditentukan pemecahan masalah yaitu mengembangkan potensi obyek wisata yang belum tergali dengan memanfaatkan dana yang tersedia, memberdayakan masyarakat di sekitar obyek wisata, meningkatkan pembinaan seni budaya daerah, melakukan koordinasi yang baik dengan lintas sektor agar pembangunan sarana dan prasarana dapat diwujudkan, melakukan kerjasama dengan sektor swasta untuk mengadakan biro perjalanan, dan meningkatkan kualitas sumber daya manusia. Dengan penerapan analisis SWOT maka pengembangan potensi pariwisata dapat dilakukan secara optimal oleh Dinas Pariwisata dan Kebudayaan Kabupaten Bulungan.

\section{SARAN}

Apabila potensi pariwisata tersebut dikembangkan secara maksimal dan terencana dengan baik tentunya akan dapat meningkatkan pendapatan asli daerah Kabupaten Bulungan dan yang paling utama adalah dapat memberikan kesempatan kerja dan berusaha bagi seluruh masyarakat dalam rangka peningkatan kesejahteraan. Dikarenakan sumber daya manusia di sektor pariwisata kurang memenuhi persyaratan, baik pendidikan maupun keahlian, membuat mereka tidak dapat mempertahankan kesesuaian langkah dengan perkembangan dan pertumbuhan industri pariwisata yang berkembang begitu cepat. Untuk mengatasi permasalahan dalam sumber daya ini, sebaiknya Dinas Pariwisata dan Kebudayaan perlu menangani pengembangan dan pelatihan sumber daya manusia secara serius. Ada beberapa faktor strategis yang perlu diperhatikan bagi pengembangan sektor pariwisata 


\section{DAFTAR PUSTAKA}

Hill, Hal, 1996, Transformasi Ekonomi Indonesia Sejak 1966, PT. Tiara Wacana, Surabaya.

Yoeti, Oka A, 1982, Pengantar Ilmu Pariwisata, Gramedia, Malang.

Yoeti, Oka A, 1996, Anatomi Pariwisata, Toga Mas, Malang. 1999, Undang-Undang Otonomi Daerah Tahun 1999, Gramedia, Surabaya.

Kusudianto, Hadinoto, 1996, Perencanaan Pengembangan Destinasi Pariwisata, UNIBRAW PRESS, Malang.

Miles, Matthew B, dan A. Michael Huberman, 1992, Analisa Data Kualitatif, UNIBRAW PRESS, Malang.

Mohyi M, Achmad, 1993, Metodologi Penelitian, UMM-Press, Malang.

Setia Tunggal, Hadi, 1999, PeraturanPerundang-undangan Kepariwisataan di Indonesia, Gramedia, Surabaya.

Sulatiyono, Agus, 2002, Manajemen Oenyelenggaraan Hotel, CV. Alfabeta, Surabaya.

illane, James J, 1987, Ekonomi Pariwisatdi Indonesia ; Sejarah dan Prospeknya, Gramedia, Malang.

Tjokroamidjojo, Bintoro, 2001, Good Governance (Paradigma Baru Manajemen Pembangunan), Gramedia, Surabaya.

Kabupaten Bulungan Dalam Angka Tahun2012, Kantor Kebudayaan dan Pariwisata, Tanjung Selor.

Indikator Sosial Ekonomi KabupateN Bulungan Tahun 2011, Kantor Kebudayaan dan Pariwisata, Tanjung Selor.

Indikator Kesejahteraan Rakyat Kabupaten Bulungan Tahun 2011, Kantor Kebudayaan dan Pariwisata, Tanjung Selor.

LAKIP Kantor Kebudayaan dan Pariwisata Kabupaten Bulungan Tahun 2011, Kantor Kebudayaan dan Pariwisata, Tanjung Selor.

Tourism Guide Book of Bulungan Regency, Kantor Kebudayaan dan Pariwisata, Tanjung Selor. 